\title{
PENGGUNAAN MEDIA BONEKA UNTUK MENGEMBANGKAN KETERAMPILAN MENYIMAK ANAK TK DI KELOMPOK B
}

\author{
Siti Rahmah Permasih ${ }^{1}$ \\ Ernalis ${ }^{2}$ \\ Tuti Istianti ${ }^{3}$
}

\begin{abstract}
ABSTRAK
Keterampilan menyimak merupakan dasar bagi seorang anak untuk dapat berbicara dengan baik. Adapun keterampilan menyimak di kelompok B TK Plus Al-Kautsar masih menunjukan perkembangan yang rendah dapat dilihat dari kurang mampunya anak merespon apa yang telah disampaikan guru. Berdasarkan permasalahan tersebut, peneliti menggunakan media boneka dalam pembelajaran untuk mengembangkan keterampilan menyimak. Penelitian ini dilaksanakan dengan desain PTK Elliot. Partisipan dan tempat penelitian ini adalah 9 anak kelompok B TK Plus Al-Kautsar Kecamatan Cimanggung Kabupaten Sumedang. Instrumen penelitian yang digunakan adalah instrumen performa, lembar observasi, lembar wawancara, catatan lapangan, dan dokumentasi. Pengumpulan data dilakukan dengan teknik observasi, wawancara, instrumen respon performa, dan dokumentasi. Data yang dikumpulkan dianalisis secara kualitatif, dan teknik triangulasi. Hasil penelitian dalam mengembangkan keterampilan menyimak dengan penggunaan media boneka mengalami peningkatan. Hal ini dibuktikan dari peningkatan ketercapaian setiap indikatornya pada setiap siklus dengan perolehan nilai rata-rata dalam setiap siklusnya terdiri Siklus I pada indikator 1 yaitu anak mampu menyebutkan tokoh yang ada dalam cerita sambil menunjukkannya, yaitu 16,67\%. Siklus II meningkat menjadi $41,91 \%$, dan pada siklus III peningkatannya sebesar $74,60 \%$. Pada indikator ke-2 yaitu anak mampu menyebutkan 3-5 urutan kata yang ada dalam cerita, siklus I kemampuan anak sebesar 15,88\%. Siklus II meningkat menjadi $30,48 \%$, dan pada siklus ke-III juga mengalami peningkatan sebesar $59,52 \%$. Pada indikator ke-3 yaitu anak mampu menceritakan kembali isi cerita. Siklus I kemampuan anak sebesar $11,12 \%$, siklus II meningkat menjadi $25,71 \%$, dan pada siklus III peningkatannya sebesar $54,76 \%$. Dengan demikian penggunaan media boneka dapat dijadikan sebagai salah satu media yang menarik minat dan antusias anak dalam pembelajaran termasuk dalam mengembangkan keterampilan menyimak anak.
\end{abstract}

Kata Kunci: Keterampilan Menyimak, Media Boneka

\footnotetext{
${ }^{1}$ sitirahmah 0694@yahoo.com

${ }^{2}$ Dosen Kampus UPI Cibiru

${ }^{3}$ Dosen Kampus UPI Cibiru
} 


\section{A. PENDAHULUAN}

Anak usia Taman Kanak-Kanak (TK) sedang berada dalam masa golden age, dimana pada masa ini semua aspek perkembangan anak sedang mengalami pekembangan yang sangat cepat sehingga sangat diperlukan stimulus yang baik dan tepat dari lingkungan sekitar agar tidak terjadi hambatan pada perkembangannya. Salah satu bentuk stimulus yang diberikan pada jalur pendidikan formal adalah melalui pendidikan Taman Kanak-Kanak. Pendidikan Taman Kanak-Kanak memiliki peranan penting dalam membantu mengoptimalkan semua aspek

perkembangan anak, sehingga anak siap untuk memasuki jenjang pendidikan selanjutnya. Salah satu aspek perkembangan yang perlu mendapatkan perhatian dalam pendidikan anak dan perlu diasah serta mendapatkan stimulusi yang tepat dan sesuai dengan tugas perkembangan anak adalah aspek perkembangan bahasa. Vygotsky (dalam Mulyasa, 2012, hlm. 21) mengemukakan

bahwa 'bahasa merupakan sumber penting dalam pendidikan anak usia dini'. melalui bahasa anak dapat memperoleh berbagai informasi, sebagai pembentukan karakter, meningkatkan proses berfikir anak dan sebagainya.

Bahasa merupakan alat bantu manusia untuk berkomunikasi, mengekspresikan pemikiran dan perasaan kepada orang lain. Melalui bahasa manusia dapat saling berinteraksi dan bersosialisasi dengan orang lain. Hal ini diperkuat juga oleh Tarigan (2013) yang menyatakan bahwa manusia dalam berkomunikasi menggunakan bahasa sebagai alatnya, baik itu dengan bahasa lisan, tulisan maupun isyarat atau gerakan.

Dalam perkembangan bahasa terdapat empat keterampilan berbahasa, yaitu keterampilan menyimak, berbicara, menulis, dan membaca. Hal ini selaras dengan yang dikemukakan oleh Tarigan (2013, hlm. 2). Keempat keterampilan tersebut saling berkaitan dan berhubungan satu dengan yang lainnya. Keterampilan bahasa yang perlu dikembangkan dan distimulus dengan baik yang pertama kali adalah keterampilan menyimak. Sejalan dengan hal tersebut, salah satu aspek yang perlu dikembangkan dalam keterampilan berbahasa adalah keterampilan menyimak.

Agar mampu berkomunikasi baik dan efektif dengan lingkungan sekitar, tentu anak harus mampu mendengarkan dan memahami apa yang orang lain katakan. Oleh karena itu kemampuan menyimak memiliki peranan penting dalam mengembangkan keterampilan bahasa lainnya karena keterampilan menyimak merupakan kemampuan awal yang perlu dimiliki oleh anak. Hal ini selaras dengan yang dikemukakan oleh Dhieni, dkk (2006) bahwa kemampuan menyimak merupakan salah satu kemampuan bahasa awal yang harus dikembangkan. Agar anak mampu memiliki kemampuan bahasa yang baik, terlebih dahulu anak harus mampu memiliki kemampuan menyimak yang baik. Di dalam proses pembelajaran anak harus mampu menyimak dengan baik agar dapat menangkap informasi yang disampaikan oleh guru dan dapat berkomunikasi dengan baik karena komunikasi atau bahasa sangatlah menentukan keberhasilan pembelajaran. Kemampuan menyimak ini sangat berhubungan dengan kemampuan mendengar dan mendengarkan, serta dalam kegiatan menyimak diperlukan perhatian dan pemahaman terhadap apa yang disampaikan kepada pendengar, sehingga dapat terjalin komunikasi dua arah. 
Adapun pengertian menyimak menurut Tarigan (2013, hlm.19)

Menyimak adalah suatu proses kegiatan mendengarkan lambang- lambang lisan dengan penuh perhatian, pemahaman, apresiasi serta interpretasi untuk memperoleh informasi, menangkap isi serta memahami makna komunikasi yang telah disampaikan oleh si pembicara melalui ujaran atau bahasa lisan.

Dalam menyimak setiap orang memiliki tujuan yang bermacam-macam, tergantung pada niat orang tersebut. Sabarti (dalam Dhieni, dkk. 2006, hlm. 4.9) mengemukakan beberapa tujuan menyimak, yaitu menyimak untuk belajar, untuk menghibur diri, untuk menilai, untuk mengapresiasi, dan untuk memecahkan masalah.

Menyimak memiliki fungsi dan peranan yang penting dalam kehidupan sehari-hari. Seperti dikemukakan oleh Adler (dalam Hermawan, 2012, hlm. 30) berdasarkan survey yang dilakukannya ternyata dalam aktivitas komunikasi persentase menyimak lebih besar dari pada membaca, berbicara dan menulis sehingga menyimak mendominasi aktivitas komunikasi. Dalam menyimak terdapat beberapa faktor yang dapat mempengaruhi menyimak. Secara umum Menurut Bromley (dalam Dhieni, dkk. 2006, hlm. 3.20) menyebutkan terdapat tiga faktor yang mempengaruhi kemampuan menyimak, yaitu faktor penyimak, pembicara ataupun dari lingkungan atau situasi.

Adapun upaya yang dapat dilakukan untuk mengembangkan keterampilan menyimak yaitu dengan penggunaan media boneka dalam pembelajaran. Pembelajaran yang diberikan dengan penggunaan media boneka yaitu dengan kegiatan bercerita.

AECT (dalam Arsyad, 2011, hlm. 3) menyatakan bahwa "media merupakan segala bentuk dan saluran yang digunakan untuk menyampaikan pesan atau informasi". Selaras dengan pendapat tersebut Heinich, dkk (dalam Eliyawati, 2005, hlm. 104) menyatakan bahwa "media merupakan alat saluran komunikasi". Berdasarkan beberapa pendapat di atas pengertian media lebih menekankan pada penyampaian informasi sehingga dapat mempermudah guru dalam menyampaikan pesan atau informasi kepada peserta didik. Media memiliki fungsi sebagai alat bantu yang digunakan guru untuk menyampaikan materi selaras dengan pendapat Hamalik (dalam Arsyad, 2011, hlm. 15) yang mengemukakan bahwa 'pemakaian media pembelajaran dalam proses belajar mengajar dapat membangkitkan keinginan dan minat yang baru, membangkitkan motivasi dan rangsangan'

Adapun pengertian dari boneka menurut Daryanto (2013, hlm. 33) menyatakan bahwa "boneka adalah benda tiruan dari bentuk manusia dan atau binatang". Terdapat berbagai macam boneka yang dapat digunakan sebagai media pembelajaran. Menurut menurut Sudjana \& Rivai (2013 : 188) mengatakan bahwa "secara umum boneka (marionette dalam bahasa Perancis), ada 2 yaitu: a.Tubuh yang dihubungkan dengan lengan, kaki dan badannya, digerakkan dari atas dengan tali-tali atau kawat-kawat halus, b.Boneka yang digerakkan dari bawah oleh seorang yang tangannya dimasukkan ke bawah pakaian boneka".

Dari pendapat di atas dapat dipahami bahwa secara umum boneka terdiri dari dua jenis yaitu boneka yang dimainkan dari atas menggunakan tali yang biasanya disebut boneka tali dan boneka yang dimainkan atau digerakkan dari bawah yang mana tangan orang yang menggerakkannya masuk kebawah pakaian boneka yang 
biasa disebut boneka tangan.

Pendapat di atas diperkuat oleh Daryanto (2013, hlm. 33) yang menyatakan bahwa macam-macam boneka dibedakan atas boneka jari, boneka tangan, boneka tongkat, boneka tali, boneka bayang- bayang. Penggunaan media boneka memiliki beberapa keuntungan, menurut Daryanto (2013, hlm. 33) menyatakan bahwa "keuntungan media boneka yaitu efisien terhadap waktu, dapat mengembangkan imajinasi dan aktivitas anak dalam suasana gembira". Dengan berbagai keuntungan yang dapat diperoleh dari media boneka tersebut maka media boneka sesuai untuk digunakan dalam pembelajaran di TK karena pembelajaran di TK harus menyenangkan.

\section{B. METODE}

Penelitian ini dilaksanakan dengan menggunakan desain PTK Elliot. Menurut Ebbut (dalam Undang, 2008, hlm. 7) menyatakan bahwa ' Penelitian Tindakan Kelas adalah kajian sitematis dari upaya perbaikan pelaksanaan praktik pendidikan oleh sekelompok guru dengan melakukan tindakan-tindakan dalam pembelajaran berdasarkan refleksi mereka mengenai hasil dari tidakan - tindakan tersebut'. Penggunaan desain PTK Elliot dikarenakan permasalahan yang ada yaitu keterampilan menyimak pada anak dalam mengmbangkannya perlu stimulus dan latihan sebagaimana menurut Dhieni, dkk (2006, hlm. 4.7) bahwa "keterampilan menyimak harus dikembangkan melalui stimulus-stimulus dan latihan-latihan karena keterampilan berbahasa tidak akan dapat dimiliki secara optimal termasuk menyimak di dalamnya kalau tidak dikembangkan dan dilatihkan". Selain itu penggunaan desain PTK Elliot karena desain penelitian ini dipandang lebih detail sehingga analisis dan refleksi dalam model ini tidak cukup hanya dilakukan dalam satu tindakan saja namun perlu dilakukan dalam beberapa tindakan dalam satu siklus yang utuh. Hal ini selaras dengan pendapat yang dikemukakan oleh Elliot (dalam Abidin, 2011) bahwa implementasi tindakan tidak semuanya mudah, perlu dilakukan secara bertahap dalam beberapa tindakan dan analisis serta refleksi yang dilakukan tidak pertindakan namun persiklus.

Menurut desain Elliot penelitian yang akan dilaksanakan terdiri dari 3 siklus dimana pada setiap siklusnya terdiri dari 3 tindakan.

Partisipan dalam penelitian ini adalah para siswa atau anak kelompok B di TK Plus Al-Kautsar yang berusia antara 5-6 tahun yang berjumlah 9 anak, terdiri dari 3 orang anak laki-laki dan 6 orang anak perempuan. 
Instrumen yang digunakan antara lain instrumen performa, lembar observasi, lembar wawancara, catatan lapangan, dan dokumentasi. Menurut Hendriana dan Afrianto (2014, hlm. 71) menyatakan bahwa "instrumen penelitian adalah alat yang digunakan untuk mengumpulkan data, seperti tes, kuesioner, wawancara, atau yang lainya". Pengumpulan data dilakukan dengan teknik observasi, wawancara, Instrumen respon performa, dan dokumentasi. Kemudian data yang sudah dikumpulkan dilakukan analisis data. Menurut Sugiyono (2009, hlm. 244) menyatakan bahwa "analisis data adalah proses mencari dan menyusun secara sistematis data yang diperoleh dari hasil wawancara, catatan lapangan, dan bahanbahan lain, sehingga dapat mudah difahami, dan temuannya dapat diinformasikan kepada orang lain." Analisis data yang akan dilakukan dengan analisis data kualitatif dan teknik triangulasi.

\section{PEMBAHASAN}

Dalam pelaksanaan penelitian ini diawali dengan perencanaan yaitu mempersiapkan berbagai perlengkapan penelitian. Hal-hal yang perlu dipersiapkan adalah rencana kegiatan harian $(\mathrm{RKH})$, alat dan media pembelajaran termasuk media boneka, cerita, serta berbagai instrumen penelitian.

Penelitian siklus I dilaksanakan pada tanggal 29 April, 6 dan 8 Mei 2015. Siklus II pada tanggal 18, 20 dan 21 Mei 2015. Siklus III pada tanggal 25, 26, dan 27 Mei 2015. Berdasarkan waktu tersebut, setiap siklus dilaksanakan selama 3 hari dengan satu hari satu tindakan. Setiap tindakan pada setiap siklusnya memiliki fokus yang sama yaitu keterampilan menyimak anak dilihat dari kemampuan anak dalam menyebutkan tokoh, urutan kata dan menceritakan kembali. adapun kegiatan pengembangan keterampilan menyimak dengan menggunakan media boneka dilakukan melalui kegiatan bercerita. Pada setiap tindakan cerita yang diberikan berbeda. Tindakan dilaksanakan dengan mengacu pada RKH yang terdiri dari kegiatan awal, inti, istirahat, dan akhir.

Kegiatan bercerita dilakukan pada kegiaatan awal, yang dimulai dengan pengkondisian anak, penyampaian cerita, evaluasi dan mendengarkan kembali cerita dari anak. Berbagai temuan esensial yang ditemukan pada setiap siklusnya adalah sebagai berikut 1 . Siklus I

Pada siklus I kegiatan menyimak dilakukan melalui kegiatan bercerita menggunakan media boneka jari. Pada tindakan I, kegiatan bercerita yang disampaikan berjudul "Dogy dan Pushi", tindakan II cerita yang diberiakan berjudul "Kelinci Pembohong" dan pada tindakan III ceritanya berjudul "Ayo Berbagi". Pada saat proses pembelajaran menggunakan media boneka, anak masih belum mampu terkondisikan saat tanya jawab. Aktivitas dalam pembelajaran dan kemampuan anak menyimak dengan penggunaan media boneka jari masih belum tampak sesuai harapan. Hal tersebut berdasarkan pada temuan yang diperoleh bahwa pada saat kegiatan bercerita anak masih belum sungguh-sungguh menyimak cerita yang diberikan peneliti menggunakan media boneka jari, anak lebih tertarik dan terfokus pada media yang digunakan tanpa menyimak cerita yang diberikan, hal tersebut menandakan kemampuan peneliti dalam menyampaikan cerita masih dirasa kurang menarik minat anak untuk benar- benar menyimak cerita yang 
diberikan, penekanan kata, kesesuaian intonasi masih harus diperbaiki. Kemampuan peneliti dalam menyampaikan cerita merupakan salah satu faktor yang dapat mempengaruhi keterampilan menyimak anak, menurut Bromley (dalam Dhieni, dkk. 2006, hlm. 3.20) yang menyebutkan bahwa salah satu faktor yang dapat mempengaruhi menyimak anak adalah faktor pembicara dimana guru sebagai pembicara perlu menyampaikan pesan dengan berbagai cara sehingga anak dapat menyimak secara efektif. Kemampuan menyimak anak melalui penerapan media boneka masih belum terlihat peningkatannya, belum ada anak yang mampu menyebutkan tokoh yang ada dalam cerita dan menceritakan kembali cerita secara runtut, dan hanya satu anak yang mampu menyebutkan 3-5 urutan kata

Pada tindakan II, dalam aktivitas pembelajaran untuk mengembangkan keterampilan menyimak melalui penerapan media boneka, terlihat sedikit peningkatan dalam antusias, kemauan dan kemampuan anak untuk menjawab, serta mampu melihat dan mendengarkan cerita sampai. Dalam kemampuan menyimak juga mulai terlihat peningkatan. Anak sudah mulai mampu untuk menyebutkan tokoh dengan tepat, dan menyebutkan urutan kata, sedangkan dalam menceritakan kembali cerita secara runtut belum ada anak yang mampu. Ada sebagian anak yang sudah dapat merespon pertanyaan peneliti seputar cerita.

Pada tindakan III kembali terjadi peningkatan pada kemampuan anak, namun pada proses pembelajaran mengembangkan keterampilan menyimak dengan penerapan media boneka dalam aktivitas anak tepatnya pada aktivitas melihat dan mendengarkan cerita sampai selesai terjadi sedikit penurunan. Dari yang sebelumnya hanya dua anak yang tidak melihat dan mendengarkan cerita sampai selesai, pada tindakan III bertambah menjadi empat anak. Hal tersebut terjadi karena kurangnya motivasi serta antusias anak untuk menyimak cerita sehingga dalam kegitan bercerita ada anak yang mengobrol. Antusias anak juga masih belum meningkat, anak cendrung sedikit mengalami menurun dalam antusiasnya. Namun demikian kemampuan menyimak anak sedikit mengalami peningkatan terutama dalam menceritakan kembali dan menyebutkan tokoh cerita.

Pada setiap tindakan di siklus I terjadi peningkatan proses aktivitas anak dan kemampuan menyimak anak, walaupun peningkatan tersebut belum signifikan dan belum mampu mencapai hasil yang diharapkan. Adapun hasil penilaian kemampuan anak pada siklus I peningkatan menyimak anak diambil dari indikator yang mendapatkan bintang tertinggi atau bintang 4 karena akan dilihat hasil peningkatan dari tindakan yang telah dilakukan untuk mengembangkan keterampilan menyimak anak yaitu sebagai berikut.

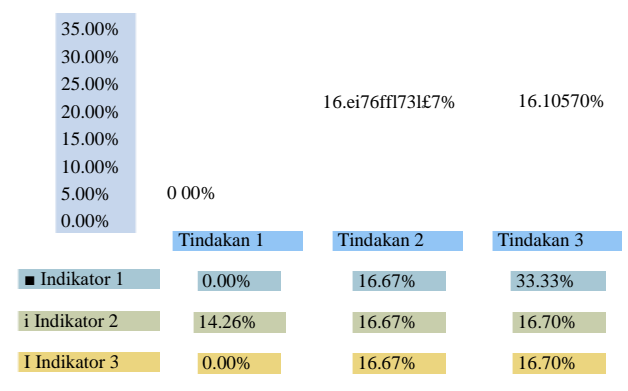


Berdasarkan grafik di atas, dapat diketahui bahwa pencapaian indikator hasil keterampilan menyimak anak melalui penggunaan media boneka pada siklus I belum sesuai dengan pencapaian yang di harapan peneliti.

Pada siklus ke-II peneliti memberikan cerita dengan menggunakan media boneka wayang agar anak lebih antusias dan tertarik terhadap cerita yang akan diberikan. Cerita yang akan diberikan juga berbeda pada setiap tindakannya. Pada tindakan I, cerita yang diberikan berjudul "Tiga Sahabat", tindakan II ceritanya berjudul "Nisa dan bunga-bunganya", dan tindakan III cerita yang diberikan berjudul "Kue Jahe".

Pada tindakan I, sebelum kegiatan bercerita dimulai anak terlihat antusias, namun pada saat kegiatan bercerita masih ada tiga anak dari lima anak yang hadir yang masih terlihat belum antusias. Hal tersebut menandakan kemampuan peneliti dalam bercerita masih perlu diperbaiki. Pada aktivitas anak terjadi peningkatan terutama dalam melihat dan mendengarkan cerita, namun anak masih belum mampu terkondisikan dengan baik. Anak sedikit kesulitan dalam menggunakan media karena ukurannya yang sedikit terlalu besar. Kemampuan anak dalam menyimak juga mengalami peningkatan. Dua anak sudah mampu menyebutkan tokoh yang ada dalam cerita, masing-masing satu anak mampu menyebutkan urutan kata dan menceritakan kembali cerita.

Pada tindakan II, aktivitas anak selama proses kegiatan bercerita menggunakan media boneka mengalami peningkatan. Anak sudah mulai mampu untuk melihat dan mendengarkan cerita dan menjawab pertanyaan seputar cerita serta mulai banyak anak yang antusias. Kemampuan menyimak anak meningkat pada semua indikator walaupun untuk pencapaian hasil yang diharapkan masih harus terus ditingkatkan. Tiga anak sudah mampu menyebutkan tokoh yang ada dalam cerita, masing-masing dua anak sudah mampu menyebutkan urutan kata dan menceritakan kembali cerita secara runtut. Hampir semua anak senang dengan cerita menggunakan media boneka yang disampaikan. Namun pada saat anak menceritakan kembali cerita masih ada anak yang belum terkondisikan sehingga mengganggu anak yang sedang bercerita, selain itu saat cerita diberikan anak mulai terlihat bosan dengan cerita yang diberikan sehingga perlu pemilihan cerita yang menarik.

Pada tindakan III, aktivitas anak selama proses pengembangan keterampilan menyimak melalui penerapan media boneka kembali mengalami peningkatan. Semua anak sudah terlihat antusias dan mampu melihat serta mendengarkan cerita sampai selesai, tidak ada anak mengobrol dan melamun, anak sudah mulai mampu menyimak cerita yang diberikan, hal tersebut terlihat dari kemampuan menyimak anak yang mengalami peningkatan, masing-masing tiga anak yang mampu menyebutkan tokoh dan menirukan urutan kata, dua anak sudah mampu menceritakan kembali cerita. Anak-anak terlihat senang ketika cerita menggunakan media boneka diberikan, selain dengan penggunaan media boneka, motivasi anak dalam menyimak cerita mulai mengalami peningkatan setelah diberikannya reward berupa bintang terutama pada tindakan I. Hal tersebut menandakan bahwa motivasi memang merupakan salah satu faktor yang dapat mempengaruhi menyimak. Menurut Tarigan (2013, hlm. 105) terdapat delapan faktor yang dapat mempengaruhi menyimak yang salah satunya adalah faktor motivasi. Ketika 
seseorang memiliki motivasi yang kuat dalam melakukan sesuatu tentu akan diharapkan mencapai tujuan, begitu juga dengan menyimak. menurut Bromley (dalam Dhieni, dkk. 2006, hlm. 3.20) menyebutkan bahwa 'Anak yang tidak memilik motivasi atau alasan kuat dalam menyimak informasi, seringkali memiliki masalah dalam memahami informsi tersebut'. Sehingga motivasi ini merupakan salah satu faktor yang penting dalam menyimak. dengan adanya reward berupa bintang dapat memotivasi anak untuk mencapai tujuan. Pada setiap tindakan di siklus II terjadi peningkatan proses aktivitas anak dan kemampuan menyimak anak, walaupun peningkatan tersebut belum signifikan dan belum mampu mencapai hasil yang diharapkan. Adapun hasil penilaian kemampuan anak pada siklus II peningkatan menyimak anak diambil dari indikator yang mendapatkan bintang tertinggi atau bintang 4 karena akan dilihat hasil peningkatan dari tindakan yang telah dilakukan untuk mengembangkan keterampilan menyimak anak. yaitu sebagai berikut.

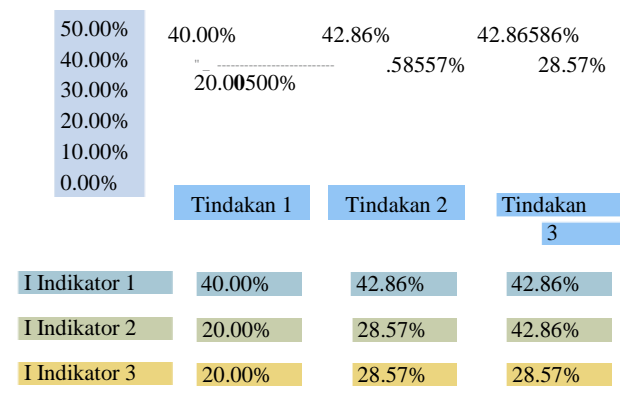

Berdasarkan grafik di atas, dapat diketahui bahwa pencapaian indikator hasil keterampilan menyimak anak melalui penggunaan media boneka pada siklus II sudah mulai mengalami peningkatan. Semua indikator pada setiap tindakan mengalami peningkatan, namun indikator 3 pada tindakan 2 dan 3 masih tetap sama. 3. Siklus III

Pada siklus III, kegiatan pengembangan menyimak anak masih dengan bercerita hanya media dan cerita yang digunakan berbeda. Media yang digunakan adalah boneka tangan dengan cerita berjudul "Monyet yang suka menolong", tindakan II ceritanya berjudul "Petualangan Ulat Kecil", dan tindakan III, cerita yang diberikan berjudul "Ani dan Hewan Kesayangan". Sebelum dan ketika peneliti bercerita menggunakan media boneka tangan semua anak terlihat antusias, semua anak melihat dan mendengarkan cerita serta ikut bernyanyi bersama tokoh cerita meskipun masih terbata-bata, namun pada saat tanyajawab dan menceritakan kembali cerita, masih ada anak yang tidak antusias dan malu dalam kegiatan tanya jawab, namun demikian terjadi peningkatan dalam proses aktivitas anak. Anak masih belum terkondisikan dengan baik pada saat menceritakan kembali cerita. Dalam kemampuan menyimak anak juga mengalami peningkatan dari siklus sebelumnya terutama pada indikator menyebutkan nama tokoh, empat anak sudah mampu menyebutkan tokoh yang ada dalam cerita, masing-masing tiga anak sudah mampu mengucapkan urutan kata serta mampu menceritakan kembali cerita.

Pada tindakan II, semua anak sudah antusias terhadap cerita yang diberikan menggunakan media boneka tangan, anak juga melihat dan mendengarkan cerita 
sampai selesai tanpa ada yang mengobrol serta merespon dan menjawab pertanyaan peneliti. Anak terlihat senang saat peneliti bercerita menggunakan media boneka tangan, dan anak ikut bernyanyi bersama tokoh cerita, dan ketika tokoh cerita bertanya kepada anak, anak merespon. Sehingga proses aktivitas anak dalam menyimak mengalami peningkatan yang cukup signifikan. Kemampuan menyimak anak juga mengalami peningkatan, lima anak sudah mampu untuk menyebutkan tokoh cerita dan empat anak sudah mampu menirukan urutan kata, serta empat anak juga sudah mampu menceritakan kembali cerita secara runtut. Namun demikian masih tetap ada dua anak yang masih malu.

Pada tindakan III, dalam proses aktivitas pengembangan keterampilan menyimak melalui pengunaan media boneka semua anak sudah terlihat antusias pada saat kegiatan, semua anak melihat dan mendengarkan cerita yang diberikan sampai selesai tanpa ada yang mengobrol atau melamun, sehigga anakpun mampu untuk menjawab dan merespon pertanyaan peneliti. Proses aktivitas pengembangan keterampilan menyimak anak sudah meningkat sesuai dengan harapan. Kemampuan anak dalam menyimak juga mengalami peningkatan yang cukup signifikan, enam anak sudah mampu menyebutkan tokoh yang ada dalam cerita, lima anak sudah mampu mengucapkan urutan kata dan empat anak sudah mampu menceritakan kembali cerita secara runtut. Pemberian stimulus dan penguatan pada anak yang pemalu juga masih dirasa kurang, akan tetapi dengan penggunaan media boneka yang berbeda pada setiap siklusnya sudah mampu memotivasi anak dan meningkatkan antusias anak dalam menyimak cerita sehingga keterampilan menyimak anak semakin meningkat pada setiap siklusnya. Hal tersebut menandakan bahwa media yang digunakan sudah menarik minat anak untuk melihat cerita sesuai dengan pendapat Hamalik (dalam Arsyad, 2011, hlm. 15) yang mengemukakan bahwa 'pemakaian media pembelajaran dalam proses belajar mengajar dapat membangkitkan keinginan dan minat yang baru, membangkitkan motivasi dan rangsangan'. Selain itu dengan penggunaan media boneka yang berbeda, membuat anak menjadi lebih senang dan antusias dalam kegiatan bercerita. Hal tersebut merupakan salah satu keuntungan dari media boneka. Menurut Daryanto (2013, hlm. 33) menyatakan bahwa "keuntungan media boneka yaitu efisien terhadap waktu, dapat mengembangkan imajinasi dan aktivitas anak dalam suasana gembira".Pada setiap tindakan di siklus III terjadi peningkatan proses aktivitas anak dan kemampuan menyimak anak, walaupun peningkatan dalam penigkatan kemampuan anak masih belum mampu mencapai hasil yang diharapkan. Adapun hasil penilaian kemampuan anak pada siklus III peningkatan keterampilan menyimak anak dari tindakan yang telah dilakukan sebagai berikut.

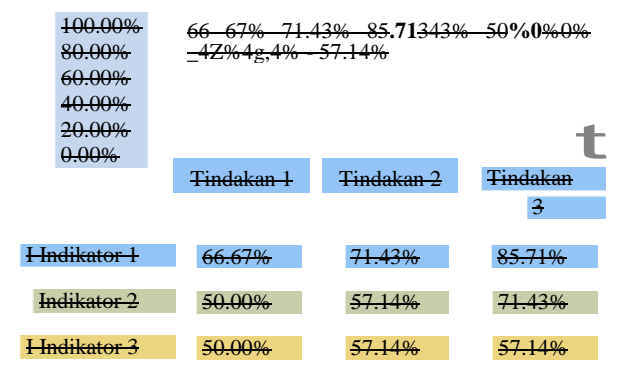


Berdasarkan grafik di atas, dapat diketahui bahwa pencapaian indikator hasil keterampilan menyimak anak melalui penggunaan media boneka pada siklus III sudah mengalami peningkatan. Semua indikator pada setiap tindakan mengalami peningkatan.

Adapun hasil akhir keterampilan menyimak anak usia TK Bdengan menerapkan media boneka pada setiap siklusnya dapat dilihat peningkatannya pada grafik di bawah ini.

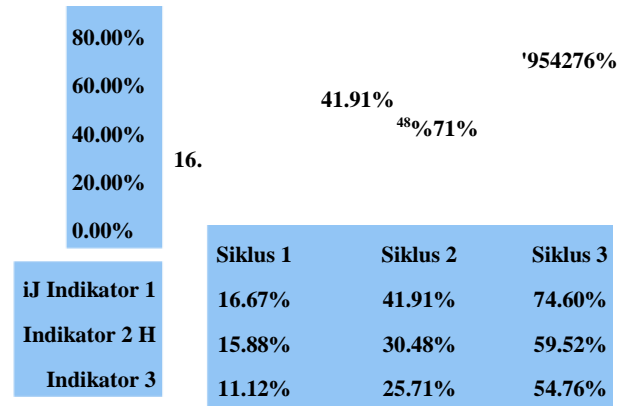

Berdasarkan grafik di atas dapat diperoleh gambaran bahwa penggunaam media boneka pada penelitian yang dilakukan di TK Plus Al-Kautsar dalam mengembangkan keterampilan menyimak telah mampu memperbaiki proses dan hasil belajar anak. Proses pembelajaran untuk mengembangkan keterampilan anak pada setiap siklusnya mengalami peningkatan, dari setiap siklus dan tindakan peneliti sudah mampu untuk memperbaiki kekurangannya, selain itu pembelajaran juga lebih menarik dengan penggunaan media boneka dan cerita yang beragam pada setiap siklus dan tindakannya serta pemberian perlakuan guru sebagai penunjang anak mampu menyimak yang semakin baik. Perkembangan keterampilan menyimak terlihat dari peningkatan keterampilan menyimak anak dari siklus I sampai siklus III. Adanya peningkatan keterampilan menyimak anak terlihat dari aktivitas dan indikator maksimal yang dihasilkan pada siklus III yang menunjukan keberhasilan dalam penelitian ini. Melalui media boneka yang digunakan dan penyampaian cerita yang menarik serta kegiatan pembelajaran yang menyenangkan dapat meningkatkan keterampilan menyimak anak. Penggunaan bahasa tubuh maupun ekspresi yang digunakan, pemberian tepuk atau sahutan dalam pengkondisian anak, pemberian hadiah/reward maupun penguatan positif terhadap anak merupakan sesuatu faktor yang mendukung terhadap penelitian yang dilakukan.

Dengan meningkatnya keterampilan anak dalam menyimak menggunakan media boneka pada setiap siklusnya menunjukkan dalam proses aktivitas pembelajarannya juga mengalami peningkatan. Berdasarkan pada penilaian performa dan observasi anak dalam kegiatan menyimak didapat berbagai temuan penting pada setiap tindakan dalam setiap siklus, kendala atau permasalahan yang dihadapi dapat teratasi dengan adanya refleksi dan pelaksanaan tindakan sebanyak sembilan kali. Dari hasil wawancara dengan bebarapa anak diketahui bahwa anak merasa senang karena penggunaan media boneka yang menarik terutama pada siklus III anak begitu antusias.

Meningkatnya keterampilan

menyimak anak dengan penggunaan media boneka bukan berarti peneliti 
terlepas dari berbagai keterbatasan. Keterbatasan peneliti dalam proses pembelajaran mengembangkan keterampilan menyimak pada anak melalui penggunaan media boneka yaitu dalam penyampaian cerita dengan menggunakan media boneka peneliti masih harus terus memperbaiki cara penyampaian sehingga dapat lebih menaik minat anak untuk menyimak apa yang disampaikan.

Dengan demikian, penggunaan media boneka untuk mengembangkan keterampilan menyimak pada anak TK Plus Al-Kautsar kelompok B telah berhasil. Penggunaan media boneka dapat meningkatkan kualitas proses dan hasil pembelajaran, yaitu meningkatkan aktivitas anak dan kemampuan anak dalam menyimak sehingga tingkat perkembangan bahasa anak di TK Plus Al-Kautsar berkembang sesuai harapan.

\section{PENUTUP}

Secara umum proses pembelajaran untuk mengembangkan keterampilan menyimak menggunakan media boneka pada setiap siklusnya semakin berkembang. Proses pembelajaran dalam mengembangkan keterampilan menyimak dilakukan dengan kegiatan bercerita. Dengan penggunaan media boneka yang beragam dan menarik serta didukung dengan pemberian cerita yang berbeda pada setiap tindakannya disertai penyampaian cerita yang menarik dan pemberian reward dapat memberikan implikasi yang baik pada anak. Dengan proses yang sedemikian rupa tersebut motivasi anak dalam menyimak semakin tinggi, hal tersebut dapat dilihat dari ketercapaian aktivitas anak saat menyimak, seperti anak mampu untuk melihat dan mendengarkan cerita sampai selesai, anak antusias saat kegiatan, dan anak mampu untuk menjawab dan merespon pertanyaan seputar cerita. Pada setiap siklusnya anak sudah mampu memperlihatkan peningkatan dalam aktivitas pengembangan keterampilan menyimak melalui penggunaan media boneka. bahkan pada sikus III tindakan ke-3 semua anak sudah mampu mencapai semua aktivitas kegiatan menyimak.

Adapun hasil kemampuan anak dalam mengembangkan keterampilan menyimak dengan menerapkan media boneka di TK Plus Al-Kautsar kelompok B mengalami perkembangan pada setiap siklusnya. Perkembangan tersebut dapat terlihat dari peningkatan ketercapaian setiap indikatornya. Selain itu anak juga lebih berani dan percaya diri dalam menceritakan dan merespon seputar cerita. Adapun hasil kemampuan anak dalam mengembangkan keterampilan menyimak dengan menerapkan media boneka yaitu pada siklus I pada indikator 1 yaitu anak mampu menyebutkan tokoh yang ada dalam cerita sambil menunjukkannya masih rendah yaitu $16,67 \%$. Pada siklus II terjadi peningkatan yang cukup signifikan yaitu $41,91 \%$, anak mulai mampu menyebutkan tokoh yang ada dalam cerita sambil menunjukkannya dari yang sebelumnya anak masih belum mampu, dan pada siklus III rata-rata kemampuan anak sebesar $74,60 \%$, hampir semua anak sudah mampu untuk menyebutkan sambil menunjukkan tokoh yang ada dalam cerita dengan tepat semua. Pada indikator ke-2 yaitu anak mampu menyebutkan 3-5 urutan kata yang ada dalam cerita. Pada siklus I kemampuan anak sebesar 15,88\%, yang berarti kebanyakan anak masih belum mampu untuk menyebutkan 3-5 urutan kata yang ada dalam cerita dengan tepat dan berurutan. Pada siklus II mengalami peningkatan menjadi 30,48\%, anak sudah mulai mampu menyebutkan 3-5 urutan kata dan pada 
siklus ke-III juga mengalami peningkatan sebesar 59,52\%, anak sudah mampu untuk menyebutkan 3-5 urutan kata. Pada indikator ke-3 yaitu anak mampu menceritakan kembali isi cerita. Siklus I kemampuan anak rata-rata persentasenya yaitu $11,12 \%$, yang berarti bahwa masih banyak anak yang belum mampu dalam menceritakan kembali cerita secara runtut, anak masih malu dalam menceritakan kembali cerita. Pada siklus II mengalami peningkatan sebesar $25,71 \%$, sudah mulai banyak anak yang mampu untuk menceritakan kembali cerita dan pada siklus III kemampuan anak mengalami peningkatan sebesar 54,76\%, yang berarti bahwa kebanyakan anak sudah mampu untuk menceritakan kembali cerita yang telah disampaikan dengan runtut dan anak sudah berani untuk menceritakannya di depan teman-temannya

\section{DAFTAR PUSTAKA}

Abidin, Y. (2011). Penelitian Pendidikan dalam Gamintan Pendidikan Dasar danPAUD. Bandung: Rizqi Press

Abidin, Y. (2012). Pembelajaran Bahasa Berbasis Pendidikan Karakter. Bandung: PT Refika Aditama.

Arsyad, Azhar. (2011). Media Pembelajaran. Jakarta: PT Raja Grafindo Persada

Daryanto. (2013). Media Pembelajaran (Peranannya Sangat Penting dalam Mencapai Tujuan Pembelajaran). Yogyakarta: Gava Media

Dhieni, N. Dkk. (2006). Metode Pengembangan Bahasa. Jakarta: Universitas Terbuka

Eliyawati, Cucu. (2005). Pemilihan dan Pengembangan Sumber Belajar untuk Anak Usia Dini. Jakarta: DEPDIKNAS Direktorat Jenderal Pendidikan Tinggi.

Hendriana dan Afrilianto, (2014). Panduan bagi Guru Penelitian Tindakan Kelas suatu Karya Tulis Ilmiah. Bandung: PT Refika Aditama

Hermawan, H. (2012). Menyimak; Keterampilan Berkomunikasi yang Terabaikan. Yogyakarta: Graha Ilmu

Mulyasa, H.E. (2012). Manajemen PAUD. Bandung: Rosda.

Sudjana \& Rivai. (2013). Media Pengajaran. Bandung: Sinar Baru Algensindo Bandung

Sugiyono. (2009). Metode Penelitian Pendidikan (Pendekatan Kuantitatif, Kualitatif, dan R\&D). Bandung: Alfabeta

Tarigan, H. (2013). Menyimak. Bandung: Angkasa

Undang, G. (2008). Teknik Penelitian Tindakan Kelas. Bandung: Sayagatama 